\title{
Why Terrorism Works: Understanding the Threat, Responding to the Challenge
}

Alan Dershowitz

New Haven: Yale University Press, 2002 (271 pp.)

Reviewed by Russ Weninger ${ }^{\dagger}$

Alan Dershowitz, in his fascinating book, Why Terrorism Works: Understanding the Threat, Responding to the Challenge, ${ }^{1}$ claims that terrorism can be part of a rational political strategy. ${ }^{2} \mathrm{He}$ argues that Palestinian terrorism has historically been an example of such rational terrorism. Dershowitz contrasts this type of terrorism with megalomaniac terrorism, as employed by al-Qaeda. The former is capable of being discouraged, while the latter is not.

Dershowitz argues that since rational terrorism is geared towards certain political interests, such as Palestinian statehood, it can be discouraged by reacting in a way that decreases the apparent likelihood that those interests will be satisfied. To the extent that this is not done, terrorism will continue. By way of example, Dershowitz draws upon correlations between Palestinian hijackings and other terrorist acts on the one hand, and international recognition of the Palestinian people and the legitimacy of some of their complaints on the other. Dershowitz claims that Palestinian terrorism has led to such recognition and has therefore proven to be a rational strategy for promoting the Palestinian cause.

The solution is then to react to acts of Palestinian terrorism by denouncing those acts in the international arena and by hindering Palestinian interests in recognition and statehood until such terrorism ceases. As he puts it:

\footnotetext{
$\dagger$ Russ Weninger is a third year law student at Dalhousie University.

${ }^{1}$ Alan Dershowitz, Why Terrorism Works (New Haven: Yale University Press, 2002).

${ }^{2}$ Dershowitz employs a notion of rationality which is arguably different from the common legal notion of reasonableness. In this notion, behaviour is rational to the extent that it promotes one's subjective interests, whatever those interests may be.
} 
If the cause is just, it should be considered--in the order of its justness compared with that of other causes, discounted by the penalty that must be imposed for resorting to terrorism. ${ }^{3}$

Dershowitz's treatment of the Palestinian situation is one-sided. The actions of Israeli soldiers are characterized as being morally superior, regardless of civilian deaths at their hands, because they apparently do not directly target innocent civilians, but kill and impoverish civilians by accident. To the extent that the Palestinian people are complicit in supporting terrorism, he continues, they are collectively responsible anyway.

The manner in which Dershowitz correlates Palestinian terrorism with success for the Palestinian cause is also questionable. Such success includes not only international recognition for their plight, but also the deaths of the victims of terrorism and the terrorists themselves, as well as the suffering of the Palestinian people. Since Dershowitz counts everything as a success, his thesis that Palestinian terrorism has been successful is trivialized. To be fair, he points out that actual success is less important, in terms of the continuance of terrorism, than perceived success. But, for Dershowitz, the perceptions that matter seem to be those of Machiavellian terrorist leaders hungry for death and publicity. While, tactically speaking, their perceptions should matter more than others, from a humanitarian perspective it seems odd to call the Palestinian cause a success, international recognition notwithstanding. Put another way, Dershowitz sees in the Palestinian people a homogeneity of interests, and this is used as an excuse to hold Palestinians collectively responsible for the actions of terrorists.

Dershowitz has a different way of dealing with terrorism of the megalomaniac variety. Such terrorists are motivated by the interests of achieving martyrdom and happiness in the afterlife. Since it may be difficult to hinder such interests, Dershowitz suggests that those terrorists must be incapacitated rather than dissuaded, and that recourse to torture may be necessary. This last claim is definitely the most controversial.

One does not expect to find a proponent of torture among the ranks of civil libertarians. Nor does one expect an argument which advocates the use of torture to be reasoned, respectful of the rule of law, and moti- 
vated, to a degree, by compassion. The effect is almost psychedelic. The legal argument for torture is summed up as follows:

Constitutional democracies are, of course, constrained in the choices they may lawfully make. The Fifth Amendment prohibits compelled self-incrimination, which means that statements elicited by means of torture may not be introduced into evidence against the defendant who has been tortured. But if a suspect is given immunity and then tortured into providing information about a future terrorist act, his privilege against self-incrimination has not been violated. (Nor would it be violated if the information were elicited by means of "truth serum," as Judge William Webster, the former head of the FBI and the CIA, has proposed--as long as the information and its fruits were not used against him in a criminal trial.) Nor has his right to be free from 'cruel and unusual punishment,' since that provision of the Eighth Amendment has been interpreted to apply solely to punishment after conviction. The only constitutional barriers would be the 'due process' clauses of the Fifth and Fourteenth Amendments, which are quite general and sufficiently flexible to permit an argument that the only process 'due' a terrorist suspected of refusing to disclose information necessary to prevent a terrorist attack is the requirement of probable cause and some degree of judicial supervision. [footnotes omitted] ${ }^{4}$

Dershowitz admits to a slight wrinkle in the legal argument insofar as the United States is a signatory to the Geneva Convention Against Torture. However, the United States adopted the convention with the reservation that it would only be bound to the extent that it was consistent with the Eighth Amendment, and American courts have decided that the Eighth Amendment does not prohibit the use of physical force to gather information necessary to save lives. ${ }^{5}$

More interesting is Dershowitz's moral argument for the permissibility of judicially warranted, non-lethal torture. The first premise is that torture sometimes elicits accurate information. Given this fact, torture could possibly be used to prevent terrorist attacks and thereby save

\footnotetext{
${ }^{4}$ Supra note 1 at 135.

${ }^{5}$ Supra note 1 at 136.
} 
lives. Dershowitz then adopts a rule utilitarian approach, which argues for adopting whatever rules lead to the best consequences overall. The claim is made that torture will happen anyway, whether being done covertly by law enforcement officials or by states who have been sub-contracted as torturers by the United States.

Since torture will happen anyways, and since it can potentially be used to save lives, the project is to devise rules that will maximize the good consequences and minimize the bad. The requirement of a judicial warrant is one such rule. Another is that the method of torture employed should not cause death or lasting injury. A third requirement is that information acquired as a result of torture should not be admissible in court against the person tortured. Proposed methods include the use of a dental drill without anesthetic and the use of a sterilized needle underneath the suspect's fingernails.

Dershowitz points out that there is prima facie inconsistency in supporting the death penalty, as many American's do, yet not supporting the use of torture. He also points out that police and prosecutors frequently resort to what would likely amount to psychological torture when they threaten suspects with the possibility of prison rape. However, for those who oppose torture and the death penalty, not to mention threats of sexual assault made by officials, there is no inconsistency.

As to the rest of the moral argument, Dershowitz may not have gone far enough in considering the consequences of torture. He acknowledges that states, rather than individuals, have historically committed the greatest atrocities. Dershowitz even quotes an Italian official who refused to torture a suspected kidnapper in the interests of freeing a former prime minister, because "Italy can survive the loss of Aldo Moro, but it cannot survive the introduction of torture." "If we are not careful, torture may be with us long after Islamic terrorist groups cease to operate.

Dershowitz also seems to avoid the really hard cases. What if the police have a suspect who has knowledge of an attack scheduled to occur within, say, an hour? To save lives, should the police forego the formalities of a warrant? Or what if time is not the issue, but rather the severity of the techniques employed? Someone willing to die for a cause may be willing to endure being poked with a needle underneath the fingernails. What then? And what if mistakes are made? 
Finally, Dershowitz does not acknowledge what torture would do to the torturers themselves. Good people would likely be psychologically scarred for life and cruel people would have their sadism compounded. States, as a rule, should not be involved in the psychological corruption of their officials.

In fact, Dershowitz considers other options besides torture. These include controlling the media, monitoring all communications, criminalizing the advocacy of terrorism, restricting movement, using collective punishment techniques, engaging in targeted assassinations, staging pre-emptive attacks, resorting to massive retaliation, conducting secret military trials, and torturing suspects. Dershowitz suggests that when evaluating possible responses to terrorism we should balance interests of security with the values of civil liberty and democratic accountability. On the whole, Dershowitz appears more permissive of espionage and the use of force than he is of limiting freedom of expression and the jurisdiction of civilian courts, but even there he rejects absolutism.

Dershowitz's arguments should be taken seriously. What may be dismissed out of hand in the legal profession and academia as heresy, may be highly persuasive to the police forces, militaries, and spy agencies of the world. These arguments may also persuade politicians, policy makers, and the general public. To the extent that we are not happy with that we should have reasoned counter-arguments. Further, there is presumed utility in individuals and institutions having as accurate a sense of the limits of moral permissibility as possible. To the degree that Dershowitz helps us to elucidate those limits, this book should be regarded as a contribution of value. 